\title{
NLP:n sovittamista johtamisen alueelle
}

\section{Terttu Grönfors 1995. Suorituskyvyn johtaminen. Facile Publishing: Espoo. 231 s.}

NLP (Neuro-Linguistic Programming) on eräs kiinnostavimmista viimeaikaisista johtamistaitoon ja inhimillisten voimavarojen kehittämiseen liittyvistä käsitteistä. NLP syntyi positiivisen ajattelun jälkimainingeista länsimaisen käyttäytymistieteellisen tiedon varaan. Sillä on yhteyksiä myös itämaiseen meditatiiviseen suuntaukseen, vaikkakin sekä meditaation perinne että NLP:n soveltajat tämän jyrkästi kiistävät.

Kirja NLP:n soveltamisesta johtamisen alueelle herättääkin kiinnostusta jo pelkällä ilmestymisellään. Grönfors on kytkenyt kirjassaan NLP:n organisaatioihin ja johtamiseen, pyrkien kehittämään organisaatioelämän suorituskykyä. Tässä työssä hän on joutunut käymään lävitse organisaatio- ja johtamisajattelun kehittymistä. Kehitysnäkymät on läpikäyty uudenlaisesta paradigman muutoksen viitekehyksestä, mutta siitä huolimatta pitäytyvät perinteisissä katsantokannoissa. Uusien näkökulmien ja NLP:n esittely on jäänyt vähemmälle, ehkä odotuksia pettävästi.

Grönfors erottaa toisistaan mekanistisen ja holistisen paradigman. Mekanistisen paradigman piiriin nivotaan, kuten niin monissa muissakin kirjoissa, tieteellinen liikkeenjohto, hallinnollinen koulukunta ja osa varhaisia käyttäytymisteorioita. Systeemiteoria samastuu tarkastelussa holistiseen teoriaan. Systeemiteorian piiriin luetaan kuuluviksi mm. organisaation kehittäminen, työelämän laadun kehittäminen, osallistuvan johtamistavan mallit ja uudemmat laatujohtamisen sekä itseohjautuvien tiimien näkökulmat.

Suorituskyvyn johtaminen nähdään johtamisnäkemysten viimeisimpänä kehitysvaiheena. Suorituskyvyn johtamisen historian alku liitetään systeemiteoriaan ja erityisesti palautteen käsittelyn merkityksen oivaltamiseen. Grönforsille systeemiteoria onkin viimeisin paradigma. Hän ei pidä esimerkiksi kulttuurinäkökulmaa, tai konstruktiivisia malleja, systeeminäkökulmaa viime aikaisempina tai monimutkaisempina malleina. Kumma kyllä myöskään subjektivistisemmat painotukset eivät nouse esille systeemiteorian mallinnettua todellisuutta monimutkaisempana näkökulmana, vaikka NLP tapahtuukin subjektiivisten mielikuvien uudelleen ohjelmoinninmaan tiedostamattomiin käyttäytymisstrategioihin ja muuttamaan niitä. Sisäisen keskustelun tiedostaminen vaikuttaa ihmisen suorituskykyyn.

Grönfors tuo teokseen lyhyen katsauksen kommunikaation ja motivaation teorioista. Niitä käsitellään aikaisemmin tutuksi käyneestä mekanistisen ja systeemiteoreettisen mallin viite kehyksestä.

Sisäisiä tekijöitä käsitellessään Grönfors on omimmillaan. Tässä jaksossa hän vähitellen pääsee lukijan odotukset täyttäen NLP:n käsittelyyn. Hän siteeraa NLP:stä tehtyjä ulkomaisia kirjoja todeten mm. että ihminen toimii sen mukaan, mitä hän kuvittelee olevan totta. Tämä NLP:n taustalla oleva oletus antaa mahdollisuuden muuttaa ihmisen sisäisiä malleja ja ajatuskuvioita, kunhan tunnistetaan ne ajattelumallit tai modaliteetit, jotka yhdistyvät huippusuoritukseen ja heikkoon suoritukseen. Muuttamalla modaliteetteja (tapahtumisen tapoja) esimerkiksi mielikuvaharjoitusten ja rentoutumisen avulla, voidaan pelottavat ja heikkoon suoritukseen johtavien tapahtumien taustalla olevat ajattelumallit korvata huippusuoritukseen johtaneilla ajattelumalleilla. Tämä on huippusuorituksen saavuttamisen taustalla oleva ajatus pähkinänkuoressa.

Grönforsin mukaan NLP tekee mahdolliseksi sen, että saadaan aikaan ihmisten toivomia käyttäytymismuutoksia: NLP ei hänen mukaansa ainoastaan tuo uusia mahdollisuuksia kommunikoida 
tehokkaammin ja ylläpitää kestäviä ihmissuhteita, vaan mahdollistaa myös pysyvien käyttäytymismuutosten toteuttamisen. NLP:n avulla pyritään vaikuttamaan tiedostamattomiin käyttäytymisstrategioihin ja muuttamaan niitä. Sisäisen keskustelun tiedostaminen vaikuttaa ihmisen suorituskykyyn.

\section{Mitä suoritusten johtamisella ymmärretään?}

Tutkimuksen empiirisen osan Grönfors keräsi haastatteluiden avulla. Tarkoituksena oli selvittää, niitä johto ja henkilöstöjohto ymmärtävät suorituksen johtamisella ja millaista se heidän mielestään kuuluisi olla. Grönfors haastatteli tutkimustaan varten yhteensä 62 henkilöä, joista 15 kuului ylimpään johtoon, 14 henkilöstöjohtoon ja 33 linjajohtoon.

Grönfors havaitsi aineistoaan analysoidessaan, että kaikki tutkittavat ryhmät perustivat suorituskyvyn johtamisen näkökulmansa ns. mekanistiseen paradigmaan. Haastateltavat saattoivat esimerkiksi sanoa, että ihmisiä on motivoitava tai että ihmisistä on saatava irti suoritus. Haastateltujen näkökulma oli johtajakeskeinen, johdon oli johdettava suoritusta omien toimenpiteidensä ja työkalujen sekä olosuhteiden avulla.

Useimmat haastatellut tunnistivat suorituskyvyn johtamisen keinoina ilmapiirin, tulosten ja kehityksen mittaamisen. Pääpaino oli tekijöillä, jotka liittyivät järjestelmään ja organisaatioon. Myös osallistumisen ja valtuuttamisen keinot mainittiin. Nykytilaa organisaatioissa kuvasikin Grönforsin mukaan mekanistinen näkökulma ja järjestelmäkeskeinen ajattelu.

\section{Suorituskyvyn johtaminen ei toteudu käytännössä}

Tarkasteltaessa sitä, miten suorituskyvyn johtaminen tulisi toteuttaa, nousi ihmisten oma vastuu korostetusti esille. Ihmisten välinen vuorovaikutus, avoimuus ja palaute sekä toisten kuunteleminen ovat keinoja, joilla suorituksia tulisi johtaa. Sekä johdon että henkilöstön mielestä suorituskyvyn johtamisen tulisi kehittyä kohti ihmiskeskeisempää lähestymistapaa, parempaa vuorovaikutusta, ihmissuhteita ja yhteistyötä.

Nykytilan ja toivottavan tilan välillä on suurehko juopa. Nykytilanteessa johtaminen perustuu edelleen tavoite- ja tulosjohtamiselle. Todellista ihmisten suorituskyvyn johtamista ei tapahdu. Toisilla termeillä operoiden kuin Grönforsin kirjassa on käytetty, voitaisiin sanoa, että ihmisten valmentamista huippusuoritukseen tapahtuu vain systeemien tasolla, ei ihmisten ajattelutapojen tasolla. Esimies ei ole alaistensa puolella ja pyri löytämään jokaisesta uusia alueita, joissa juuri hän voisi kehittyä. Sen sijaan esimies toimii mekaanisesti suoritusmääriä ja taloudellisia tuloksia kirjaten.

Grönforsin kirja antaa rutiininomaisesta otteestaan ja empiirisen käsittelyn kömpelyydestään huolimatta ajattelemisen aihetta jokaiselle työelämässä mukana olevalle.

\section{Pauli Juuti}

